\title{
Investment factor's role in forecasting of regional energy consumption (by the example of the Irkutsk region)
}

\author{
Anatoly Korneev ${ }^{1, *}$, Alexander Tsapakh ${ }^{1}$ \\ ${ }^{1}$ Melentiev Energy Systems Institute of Siberian Branch of Russian Academy of Sciences, Irkutsk, Russia
}

\begin{abstract}
The article examines a methodological approach to regional forecasting of power consumption. It is also analyzed the role of the investment factor in forecasting the economic development of the country and regions. By the example of the Irkutsk region it is estimated the prospective level of power consumption, which is necessary to predict the rational development of the region's fuel and energy complex in terms of social and economic as well as environmental indicators.
\end{abstract}

\section{Introduction}

The most important stage in a long-term forecasting of the development of the region's fuel and energy complex (FEC) is the electricity consumption forecasting. State forecasts of electricity consumption at the governmental and regional levels are characterized by a high volatility. For example, the electricity consumption in the Irkutsk Region for 2020, according to the 2008 forecast within the framework of the "General Scheme for the Development of the Electric Power Industry until 2020" [1], was to amount to 75 billion $\mathrm{kWh}$. According to the 2017 forecast of the "General Scheme for the Development of the Electric Power Industry until 2035" [2], electricity consumption in 2020 will decrease to 55 billion $\mathrm{kWh}$, and for 2035 it is expected to be 69 billion $\mathrm{kWh}$. One can see that the previously predicted volume of electricity consumption for 2020 is not achieved even by 2035 , according to the new forecast. Overestimated predictions of electricity consumption are usually associated with unreasonably overestimated prognosis of the economic development of the country and regions. Federal and regional authorities in their economic forecasts rely on overestimated expectations and targets, but they practically do not take into account such factors as:

- negative impact of global and country's financial and economic crises on the economy (investment and economic activity decline).

- geopolitical challenges as well as financial and economic sanctions on Russia by some developed countries.

- low level of feasibility of the proposed investment projects;

- limited investment, and so on, and so forth.

In our opinion, the main reason for obtaining insufficiently substantiated and overestimated economic forecasts is a weak accounting (or not accounting at all) of the investment factor when developing scenarios for economic development and subsequent quantitative assessments. The limited investment is associated with the restricted investors' own funds, that depend on the profit of their production activities and borrowed funds, that is on their value in the country and access to foreign financial sources. The both factors come along with Russia's investment activity not only at the present time, but as like as not in the future, however it depends on economic crises and sanctions. The low validity of forecasts indicates the relevance of improving forecasting methods in the direction of their greater adaptation to market instability and taking into account investment restrictions [3, 4$]$.

\section{Methodological approach to regional forecasting of the economy and electricity consumption, given the investment factor}

The basic methodological principle for the formation of a calculation scheme (model) for a long-term electricity consumption forecasting is the provision on the prevailing investment dependence of federal districts and their individual regions from the federal center. I.e. the investments that ensure regional economic growth, are a limited resource for the regions as well as they depend on their total country's volume, which is also limited, because it is formed in the environment of a number of unfavorable internal and external factors.

Based on this provision, at the initial stage of forecasting electricity consumption, that is, when determining the prospective indicators of the economic development of the country and regions (gross regional product or gross output), it is predicted investments in the Russian economy at large.

This forecast is carried out on the basis of the specified growth rates of investments in fixed assets, given the retrospective average annual growth rates for a long period, including both favorable and unfavorable (crisis) years of the country's economic development,

* Corresponding author: korn@isem.irk.ru 
and taking into account the scenario investment conditions in the future. Here in after it is estimated the investments in the federal districts and regions on the basis of their existing territorial structure.

In accordance with the specified volumes of the country's investments, federal districts and constituent entities of the Russian Federation, based on the production return on investment (production of the gross regional product per ruble of investment), it is calculated the total volume of the gross regional product (GRP). Prospective indicators of electricity consumption in the country and regions are calculated based on the specified coefficients of electrical intensity of the gross regional product (GRP):

$$
\mathrm{E}(t)=\mathrm{e}(t) * \mathrm{P}(t), \text { where: }
$$

$E(t)$ - electricity consumption in the regional context (whole country, Federal districts, subjects of the Russian Federation) in a year $\mathrm{t}$; $\mathrm{e}(\mathrm{t})$ - electrical intensity of GRP in the regional context; $\mathrm{P}(\mathrm{t})-\mathrm{GRP}$ in the regional context. The full scheme of the model for macroforecasting of electricity consumption at the country and regional levels is presented in [5]. Leaning on this methodological approach, it was made the forecast of power consumption in the Irkutsk region for a 15-year period (up to 2035).

\section{Requirements for mechanisms to implement inter-country projects}

The integral indicator that characterizes the level of development of the region is the GRP per capita. According to this indicator, the Irkutsk Region takes the second place after the Krasnoyarsk Region in the Siberian Federal District and the 17 th place among the regions of the Russian Federation. In 2018 it was equal to 568.5 thousand rubles and exceeded the same indicator for Russia and the Siberian Federal District as a whole (when calculating indicators for the Siberian Federal District (SFD) in 2018, it did not include the Republic of Buryatia and Transbaikal territory). (Table 1).

Table 1. Gross regional product per capita, thousand rubles

\begin{tabular}{|l|l|l|l|l|l|l|l|l|l|l|l|}
\hline \multicolumn{10}{|c|}{ Irkutsk region } & \multicolumn{9}{c|}{ Yussia } & \multicolumn{5}{|c|}{ SFD } \\
\hline \multicolumn{10}{|c|}{ Indicator } \\
\hline 2005 & 2010 & 2015 & 2018 & 2005 & 2010 & 2015 & 2018 & 2005 & 2010 & 2015 & 2018 \\
\hline \multicolumn{10}{|c|}{} \\
\hline 102.9 & 224.4 & 415 & 568.5 & 125.6 & 263.8 & 449 & 548.3 & 99.6 & 214.4 & 353 & 494 \\
\hline
\end{tabular}

Source: Region of Russia. Socio-economic indicators / Rosstat. Moscow: 2019. 1204 p.

GRP in 2018 amounted to 13.365 billion rubles in current prices and increased 2.5 times compared to 2010 , while GDP, calculated on the basis of physical growth indices, i.e. in constant prices of the 2010 base year, increased 1.3 times (Fig. 1).

During 2000-2015 the Irkutsk Region had relatively high average annual rates of economic growth at the level of $105 \%$, that is higher than the average for Russia and the Siberian Federal District. Over the past three years, the growth rate of GRP in the region has noticeably decreased, which is associated with reaching a stable volume of oil production. However, despite the consequences of the global financial and economic crisis and the sanctions policy of the Western countries in relation to Russia, for these three years the average annual GRP rate exceeded similar indicators for the country and the Siberian Federal District. (Table. 2, Fig. 2).

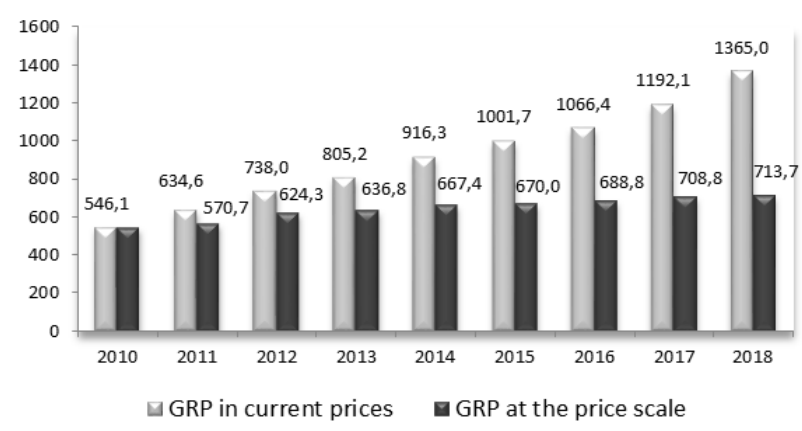

Fig. 1. Dynamics of GRP in the Irkutsk region for 2010-2018 (Source: Structure and dynamics of industrial production in the Irkutsk region. Analytical note. Irkutskstat. 2019. P. 30). (In Russian).

Table 2. The average annual indices of GRP physical volume, $\%$

\begin{tabular}{|l|c|c|c|c|c|}
\hline \multicolumn{1}{|c|}{ Indicator } & $\begin{array}{c}\text { Average } \\
\text { for } \\
\mathbf{2 0 0 0 -} \\
\mathbf{2 0 0 5}\end{array}$ & $\begin{array}{c}\text { Average } \\
\text { for } \\
\mathbf{2 0 0 5} \\
\mathbf{2 0 1 0}\end{array}$ & $\begin{array}{c}\text { Average } \\
\text { for } \\
\mathbf{2 0 1 0} \\
\mathbf{2 0 1 5}\end{array}$ & $\begin{array}{c}\text { Average } \\
\text { for } \\
\mathbf{2 0 1 5} \\
\mathbf{2 0 1 8}\end{array}$ & $\begin{array}{c}\text { Average } \\
\text { for } \\
\mathbf{2 0 0 0} \\
\mathbf{2 0 1 8}\end{array}$ \\
\hline $\begin{array}{l}\text { The growth rate of GRP in } \\
\text { Russia }\end{array}$ & 106.8 & 103.7 & 102.2 & 101.7 & 103.8 \\
\hline $\begin{array}{l}\text { The growth rate of GRP in } \\
\text { the Irkutsk region }\end{array}$ & 104.7 & 106.3 & 104.2 & 102.2 & 104.6 \\
\hline $\begin{array}{l}\text { The growth rate of GRP in } \\
\text { SFD }\end{array}$ & 106.3 & 103.5 & 102.1 & 102 & 103.6 \\
\hline Sour: Stati
\end{tabular}

Source: Statistical Yearbooks: "Socio-economic situation of the Siberian Federal District regions in 2019"; "Socio-economic situation of the Irkutsk region in 2018", Irkutskstat, 2019.

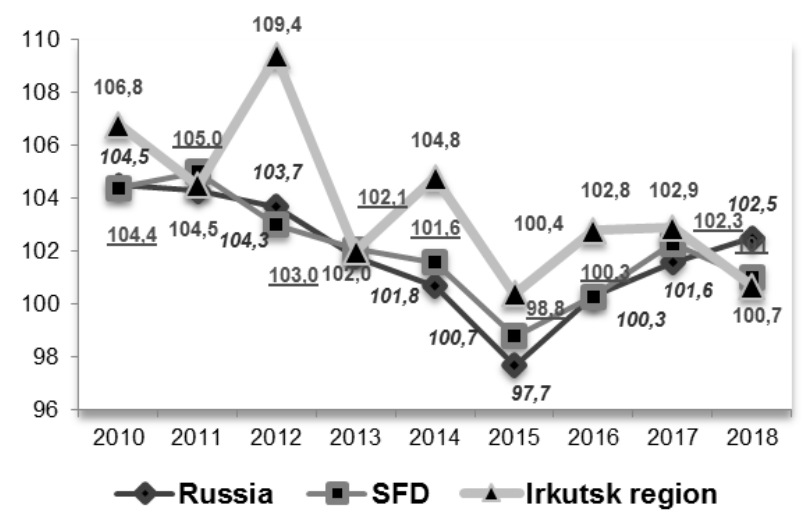

Fig. 2. Indices of the physical volume of GRP in Russia, the Siberian Federal District, and the Irkutsk region, \% to the previous year. (Source: Structure and dynamics of industrial production in the Irkutsk region. Analytical note. Irkutskstat. 2019. P. 30). (In Russian).

In the GRP production, industry is becoming increasingly important, including such activities as mining, manufacturing, electric and thermal power. Its 
share in GRP in 2017 was $45.4 \%$, which is $14 \%$ higher than in 2010. (Table 3).

Table 3. Structure of the gross value added of the Irkutsk region (as a percentage of the total)

\begin{tabular}{|l|c|c|c|c|c|c|c|c|}
\hline \multicolumn{1}{|c|}{ Indicator } & $\mathbf{2 0 1 0}$ & $\mathbf{2 0 1 1}$ & $\mathbf{2 0 1 2}$ & $\mathbf{2 0 1 3}$ & $\mathbf{2 0 1 4}$ & $\mathbf{2 0 1 5}$ & $\mathbf{2 0 1 6}$ & $\mathbf{2 0 1 7}$ \\
\hline $\begin{array}{l}\text { GRP, total, } \\
\text { including: }\end{array}$ & 100.0 & 100.0 & 100.0 & 100.0 & 100.0 & 100.0 & 100.0 & 100.0 \\
\hline $\begin{array}{l}\text { mining } \\
\text { operation }\end{array}$ & 7.5 & 13.0 & 15.7 & 18.0 & 19.6 & 24.6 & 26.2 & 27.2 \\
\hline $\begin{array}{l}\text { manufacturing } \\
\text { activity }\end{array}$ & 16.3 & 14.8 & 13.4 & 13.7 & 12.4 & 13.6 & 12.7 & 11.9 \\
\hline $\begin{array}{l}\text { production and } \\
\text { distribution of } \\
\text { electricity, gas } \\
\text { and water }\end{array}$ & 7.2 & 7.5 & 6.6 & 6.0 & 5.6 & 5.3 & 5.9 & 6.3 \\
\hline other activities & 69.0 & 64.7 & 64.3 & 62.3 & 62.4 & 56.5 & 55.2 & 54.6 \\
\hline
\end{tabular}

Source: Structure and dynamics of industrial production in the Irkutsk region. Analytical note. Irkutskstat. 2019. P. 30. (In Russian).

Investment is the main determinant of economic growth. The investment process in the Irkutsk region is in a more favorable position than in Russia as a whole and in the SFD, since the main and stable source of capital investment is the profit of enterprises operating in the region. Share of its' own funds in the structure of investments sources in fixed assets for large and medium-sized enterprises in the Irkutsk region reached $61 \%$ in 2018 (for Russia in common - $51 \%$ ). This provided a steady increase in production in the oil industry, timber processing, non-ferrous metallurgy, aircraft construction, transport, including pipeline, etc. However, the growth rate of investment in the economy of the Irkutsk region has been noticeably declining in recent years. (Fig. 3).

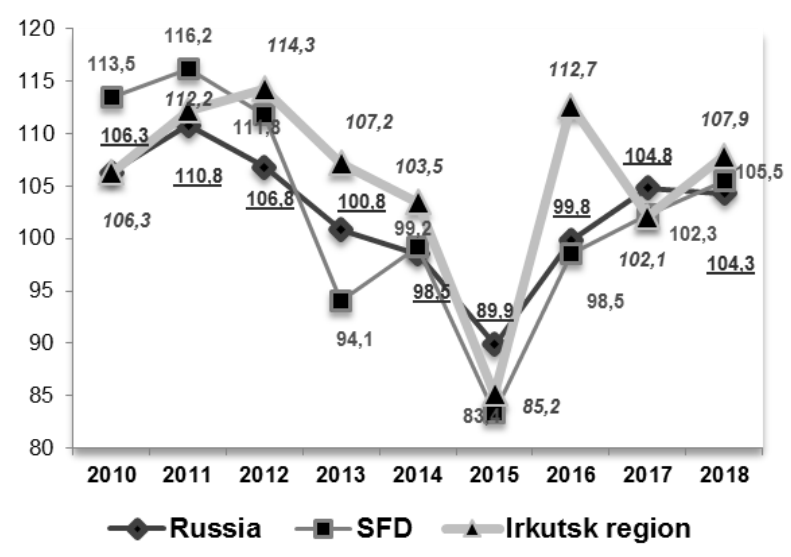

Fig. 3. Comparative dynamics of investments in fixed assets in the Irkutsk region, the Russian Federation and the SFD in comparable prices - $\%$ to the previous period. (Source: Structure and dynamics of industrial production in the Irkutsk region. Analytical note. Irkutskstat. 2019. P. 30). (In Russian).

\section{Forecast of power consumption in the Irkutsk region}

The level of demand for electricity in the future until 2035 will depend on a number of factors, the main of which are:

implementation of large electric-intensive investment projects in the extractive and manufacturing industries. The development of the raw materials sector of the regional economy is an important factor for economic growth. It is associated with the extraction of oil, gas, coal, gold, rare earth metals, etc. In the manufacturing industries there are aluminum production, timber processing, gas chemistry, etc. These types of products are competitive in the domestic and global markets due to favorable production factors;

- energy saving associated with innovative processes and investments in the modernization of existing production facilities and the renewal of production assets. Currently, the depreciation of fixed assets in the manufacturing industry is more than $60 \%$, and the level of unused obsolete production capacity reaches $30 \%$ or more;

- internal and external conditions for the development of the country's economy connected with access to investment resources, new technologies, restrictions and sanctions imposed on domestic producers in the financial, production and service sectors.

The "conservative" scenario is considered as the main (basic) scenario for the development of the Irkutsk region's economy. In the baseline scenario, up to 2025 , the internal and external conditions for the economic development of the country and regions will continue to be unfavorable, i.e. economic stagnation persists. Under these conditions, there are significant delays in the implementation of a number of major investment projects. The average annual growth rate of investment at country scale in the forecast period will remain at a relatively low level and will amount to 103-103.5\%. This will be a limiting factor for investment activity in the regions as well. In the Irkutsk region, taking into account its stable share in total investment in the country, $1.7-1.8 \%$ with a small growth forecast to $2.0 \%$ by 2035 , the average annual growth of investment may be about $104 \%$.

The gross regional product of the Irkutsk region, calculated on the basis of the investment return indicator equal to 4.0-4.3 GRP/RUB of investment, will increase by 1.5 times and will amount to 2490 billion rubles by 2035 compared to 2018. The expert forecast of changes in the dynamics of GRP electrical intensity up to 2035 took into account such factors as energy saving for electric-intensive consumers due to technological modernization of production, reduction of losses in power grids, implementation of new electric-intensive projects, introduction of "smart grid" technologies, etc. Taking into account these factors, the electrical intensity of the Irkutsk region GRP has a steady downward trend, and its level will be decreasing by about $34 \%$ over the period 2018-2035. (Table 4). 
Table 4. Main indicators related to the forecast of power consumption in the Irkutsk region

\begin{tabular}{|l|l|c|c|c|c|c|}
\hline \multirow{2}{*}{ Indicator } & \multirow{2}{*}{ Measure unit } & \multicolumn{5}{|c|}{ Год } \\
\cline { 3 - 8 } & & $\mathbf{2 0 1 8}$ & $\mathbf{2 0 2 0}$ & $\mathbf{2 0 2 5}$ & $\mathbf{2 0 3 0}$ & $\mathbf{2 0 3 5}$ \\
\hline Investment in the Irkutsk region & Billion rub. & 316 & 325 & 383 & 503 & 615 \\
\hline $\begin{array}{l}\text { Investment returns for the } \\
\text { production of GRP }\end{array}$ & Rub. & 4.3 & 4.44 & 4.43 & 4.14 & 4.0 \\
\hline $\begin{array}{l}\text { Gross regional product of the } \\
\text { Irkutsk region }\end{array}$ & Billion rub. & 1365 & 1461 & 1700 & 2202 & 2490 \\
\hline Electrical intensity of GRP & $\mathrm{kWh}$ rub. & 0.041 & 0.038 & 0.035 & 0.029 & 0.027 \\
\hline Electricity consumption & Billion kWh & 55.7 & 56.1 & 60 & 64 & 67 \\
\hline
\end{tabular}

Source: Region of Russia. Socio-economic indicators. Statistics for 2010-2019 / Rosstat. M., 2010-2019; authors estimates. (In Russian).

According to the forecast made with the including of investment restrictions of the country's and regions' economic development, the power consumption of the Irkutsk region under the conservative scenario will amount to 67 billion $\mathrm{kWh}$ by 2035 and will increase by 1.2 times compared to 2018. This level is lower than the state forecasts: according to the conservative scenario by 2 billion $\mathrm{kWh}$, and according to the target (optimistic) scenario - by 4 billion kWh.

\section{Conclusions}

1. The Irkutsk region has a high industrial, natural resource, investment and human resources potential. In the period 2000-2018, it had a relatively high average annual economic growth rate - close to $104.3 \%$, which is higher than the average indicators for Russia and the SFD.

2. The main limiting factor for the development of regional economy and electricity consumption in the period up to 2035 will be investments, the inflow of which is steadily decreasing due to economic crises, external financial and economic sanctions, technological backwardness in the production sector, etc.

The study was carried out at the expense of the RFBR Regional Project and the Irkutsk Region Government, grant № 17-48-380002 ra

\section{References}

1. General Scheme for the Development of the Electric Power Industry until 2020 published in February 22, 2008 № 215-p. [Electronic resource]. - URL: https://zakonbase.ru/content/part/572036 (accessed 25.08.2020) (In Russian).

2. General Scheme for the Development of the Electric Power Industry until 2035 published in February 22, 2008 № 215-p. [Electronic resource]. - URL: https://zakonbase.ru/content/part/572036 (accessed 07.09.2020). (In Russian).

3. N.I. Voropai, A.M. Kler, Yu.D. Kononov, B.G. Saneev, S.M. Senderov, V.A. Stennikov. Methodological Foundations of Strategic Energy
Development // Energy Policy, № 3, p. 35-41. (2018) (In Russian).

4. Kononov Yu.D. Ways to Increase the Validity of Long-term Forecasts of Fuel and Energy Industry Development. - Novosibirsk: Science, p. 34-45. (2015) (In Russian).

5. Korneev A.G. Macro-forecast of Electricity Consumption in Russia and its Eastern Regions in the Long Term // Energy Policy, № 1, p. 67-74. (2019) (In Russian). 